\title{
The Chinese Stripe-necked Turtle (Mauremys sinensis [Gray, 1834]) (Geoemydidae), Another Introduced Turtle Species in Florida
}

Dale R. Jackson

Florida Natural Areas Inventory, Florida State University, 1018 Thomasville Road, Suite 200-C, Tallahassee, Florida 32303, USA (DRJackson@admin.fsu.edu)

$\mathrm{T}$

he Chinese Stripe-necked Turtle (Mauremys sinensis [Gray, 1834], better known by its former name, Ocadia sinensis) is indigenous to southeastern China, Taiwan, Vietnam, and possibly Laos, with a latitudinal range of approximately $16-32^{\circ} \mathrm{N}$ (Iverson 1992). This freshwater species prefers still and slowly moving waters such as lakes, ponds, low-elevation rivers, reservoirs, and agricultural ditches (Chen and Lue 2009). It is listed as endangered on the IUCN Red List of Threatened Species (IUCN 2011).

On 13 July 1972, the author collected a subadult or small adult female $M$. sinensis (ca. $16 \mathrm{~cm} \mathrm{CL}$, photographic voucher UF 166135; believed to be PCHP 1085 in the Chelonia Research Institute collection) in a baited hoop trap on the eastern edge of Calf Pond, a 4.8-ha permanent lake in southeastern Gainesville, Alachua County, Florida $\left(29.6281^{\circ} \mathrm{N}\right.$, $82.2856^{\circ} \mathrm{W}$, Datum WGS84). Three species of native emydid turtles were trapped concurrently at the same site:
Deirochelys reticularia (1 male), Pseudemys floridana (1 male), and Trachemys scripta (2 females, 1 male). Subsequent investigation revealed that the Mauremys had escaped from the residence of P.C.H. Pritchard (PCHP, to whom it was returned) an estimated 15 months earlier. During its period in the wild, it not only survived one winter but also grew several $\mathrm{cm}$ (PCHP, pers. comm.; rapid growth also evident from carapacial scute annulus pattern). That it thrived is not surprising, given that northern Florida lies well within the native latitudinal limits of the species. Only one turtle, the Slider (Trachemys scripta), occurs among the 50 exotic species of amphibians and reptiles in Florida (Meshaka 2011). This specimen represents the first known voucher for this species of turtle in Florida, only the third species and second genus of the large family Geoemydidae (after two species of Rhinoclemmys), and the 140th verified non-indigenous herpetofaunal species in the state (Krysko et al. 2011; Rochford et al. 2011; K. Krysko, pers. comm.).
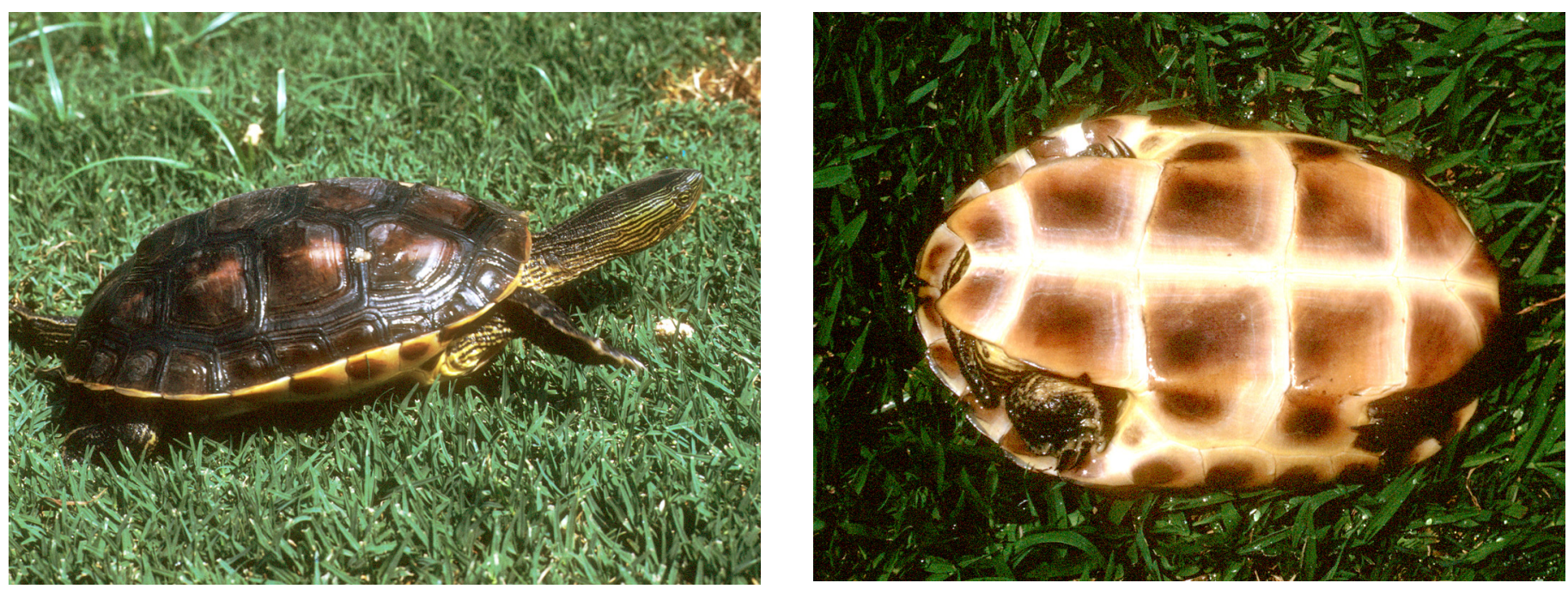

Dorsolateral and ventral views of female Chinese Stripe-necked Turtle (Mauremys sinensis, UF 166135) from Gainesville, Alachua County, Florida. Photographs by the author. 


\section{Acknowledgments}

I thank Dr. Peter C.H. Pritchard for background information about the turtle, and Dr. Kenneth L. Krysko for advice on manuscript preparation and submission.

\section{Literature Cited}

Chen, T.H. and K.Y. Lue. 2009. Changes in the population structure and diet of the Chinese Stripe-necked Turtle (Mauremys sinensis) inhabiting a disturbed river in northern Taiwan. Zoological Studies 48:95-105.

Gray, J.E. 1834. Characters of several new species of freshwater tortoises (Emys) from India and China. Proceedings of the Zoological Society of London 1834:53-55.

IUCN. 2011. IUCN Red List of Threatened Species. Version 2011.2. <www. iucnredlist.org>.

Iverson, J.B. 1992. A Revised Checklist with Distribution Maps of the Turtles of the World. Privately printed, Richmond, Indiana.

Krysko, L., J.P. Burgess, M.R. Rochford, C.R. Gillette, D. Cueva, K.M. Enge, L.A. Somma, J.L. Stabile, D.C. Smith, J.A. Wasilewski, G.N. Kieckhefer III, M.C. Granatosky, and S.V. Nielsen. 2011. Verified non-indigenous amphibians and reptiles in Florida from 1863 through 2010: Outlining the invasion process and identifying invasion pathways and stages. Zootaxa 3028:1-64.

Meshaka, Jr., W.E. 2011. A runaway train in the making: The exotic amphibians, reptiles, turtles, and crocodilians of Florida. Monograph 1. Herpetological Conservation and Biology 6:1-101.

Rochford, M.R., K.L. Krysko, and K.P. Wray. 2011. The Marbled Treefrog (Dendropsophus marmoratus [Laurenti 1768]) (Hylidae), another introduced amphibian species in Florida. Amphibians \& Reptiles 18:248. 